University of Nebraska - Lincoln

DigitalCommons@University of Nebraska - Lincoln

Papers in the Earth and Atmospheric Sciences Earth and Atmospheric Sciences, Department

7-21-2006

\title{
Large Wind Shift on the Great Plains during the Medieval Warm Period
}

\author{
Venkataramana Sridhar \\ University of Nebraska, Lincoln \\ David B. Loope \\ University of Nebraska, Lincoln, dloope1@unl.edu \\ James B. Swinehart \\ University of Nebraska-Lincoln, jswinehart1@unl.edu \\ Joseph A. Mason \\ University of Wisconsin, Madison \\ Robert J. Oglesby \\ University of Nebraska-Lincoln, roglesby2@unl.edu \\ See next page for additional authors
}

Follow this and additional works at: https://digitalcommons.unl.edu/geosciencefacpub

Part of the Earth Sciences Commons

Sridhar, Venkataramana; Loope, David B.; Swinehart, James B.; Mason, Joseph A.; Oglesby, Robert J.; and Rowe, Clinton M., "Large Wind Shift on the Great Plains during the Medieval Warm Period" (2006). Papers in the Earth and Atmospheric Sciences. 246.

https://digitalcommons.unl.edu/geosciencefacpub/246

This Article is brought to you for free and open access by the Earth and Atmospheric Sciences, Department of at DigitalCommons@University of Nebraska - Lincoln. It has been accepted for inclusion in Papers in the Earth and Atmospheric Sciences by an authorized administrator of DigitalCommons@University of Nebraska - Lincoln. 


\section{Authors}

Venkataramana Sridhar, David B. Loope, James B. Swinehart, Joseph A. Mason, Robert J. Oglesby, and Clinton M. Rowe 


\title{
Large Wind Shift on the Great Plains during the Medieval Warm Period
}

\author{
Venkataramana Sridhar, ${ }^{1,2}$ David B. Loope, ' James B. Swinehart, ${ }^{1,2}$ \\ Joseph A. Mason, ${ }^{3}$ Robert J. Oglesby, ${ }^{1,2}$ and Clinton M. Rowe' \\ I Department of Geosciences, University of Nebraska-Lincoln, Lincoln, NE 68588-0340, USA \\ 2 School of Natural Resources, University of Nebraska-Lincoln, Lincoln, NE 68583-0758, USA \\ 3 Department of Geography, University of Wisconsin, Madison,WI 53706, USA \\ Corresponding author — D. B. Loope, emaildloopel@unl.edu
}

\begin{abstract}
Spring-summer winds from the south move moist air from the Gulf of Mexico to the Great Plains. Rainfall in the growing season sustains prairie grasses that keep large dunes in the Nebraska Sand Hills immobile. Longitudinal dunes built during the MedievalWarm Period ( 800 to 1000 years before the present) record the last major period of sand mobility. These dunes are oriented NW-SE and are composed of cross-strata with bipolar dip directions. The trend and structure of the dunes record a drought that was initiated and sustained by a historically unprecedented shift of spring-summer atmospheric circulation over the Plains: Moist southerly flow was replaced by dry southwesterly flow.
\end{abstract}

Direct evidence of past changes in atmospheric circulation is largely absent from the geologic record. It is much easier to reconstruct indirect indicators of circulation such as vegetation, temperature, and precipitation. Episodically active dunes are an exception to this, however. Periods of dune activation and stabilization have frequently been used to infer alternating periods of drought and pluvial conditions, but few studies have fully exploited the orientation, morphology, and internal structures of dunes to reveal the wind regime under which they formed. We have used those features to explore paleowind regimes from the North American Great Plains.

In spring and early summer, strong southerly-to-southeasterly winds sweep over the Gulf of Mexico and transport moisture for growing-season rains to North America's core (1$3)$. Today, this moisture sustains the vegetation that stabilizes extensive dunefields on the Great Plains. A distinctive set of NW-SE-trending, grassstabilized longitudinal dunes occupies $7500 \mathrm{~km}^{2}$ of central Nebraska (Figure 1); these dunes formed only 800 to 1000 years ago, near the end of the Medieval Warm Period (MWP) $(4,5)$.
Annual precipitation ranges from $60 \mathrm{~cm}$ in the eastern Sand Hills to less than $43 \mathrm{~cm}$ in the west; $\sim 50 \%$ comes in May, June, and July (1). During the 1930s and 1950s droughts, only isolated blowouts formed in the Sand Hills. Historical accounts indicate that some dune crests were grass-free at times during the 19th century (6). The large size of stabilized dunes and the dunefield's great extent indicate that the region is prone to droughts far more severe than those in the historical record (7). Optically stimulated luminescence (OSL) ages from deep within the largest dunes extend to 15,000 years before the present ( $\mathrm{yr}$ B.P.), but shallow core and outcrop samples from dunes and adjacent wetlands indicate an episode of dune migration 800 to 1000 yr B.P., when aridity was wide-spread and persistent across western North America (8-16).

Many modern deserts contain morphologically distinct generations of dunes with different trends (17). If the internal structure and age of each generation are known, changes in regional winds can be reconstructed (18). The modern wind regime in the Sand Hills is dominated by northerly winter winds associated with midlatitude cyclones and by southerly flow in spring and summer associated with anticyclonic return flow of moist air from the Gulf of Mexico.

Dunes orient themselves to maximize sand transport normal to their crests $(19,20)$. In bidirectional flows, transverse dunes form if the divergence angle between flows is less than $90^{\circ}$ or close to $180^{\circ}$; oblique or longitudinal dunes (both with linear morphology) form if the angular difference is between $90^{\circ}$ and $165^{\circ}(19)$. Crests of longitudinal dunes lie within $15^{\circ}$ of the resultant transport vector, crests of oblique dunes lie between $15^{\circ}$ and $75^{\circ}$, and crests of transverse dunes lie between $75^{\circ}$ and $90^{\circ}$ (Figure S1) (19). Using wind data from six meteorological stations in and near the Nebraska Sand Hills (Figure 1), we used the computer program Trend $(19,21)$ to calculate the trend and resultant sand-drift vectors of dunes that would form (if sand were free to move) at each site. Trends range from $\mathrm{S} 70^{\circ} \mathrm{W}$ to $555^{\circ} \mathrm{W}$ (Figure S2). Angles between calculated dune trends and modern resultants range from $44^{\circ}$ to $90^{\circ}$ and show that modern winds would generate oblique and transverse dunes, both of which would migrate southeastward; internally, these dunes contain only southwarddipping cross-strata (Figure 2). 
Figure I. Locations of weather stations and extent of $\mathrm{Ne}$ braska Sand Hills (light gray shading) and longitudinal dunes with NW-SE trends (dark gray shading). Wind data stations and periods of record are as follows: A, Ainsworth, 1973-2005; B, Brewster, 1973-1979 and 1996-2005; BB, Broken Bow, 1973-2005; NP, North Platte, |973-2005; ON, O'Neill, I984-199| and 1995-2005; OR,

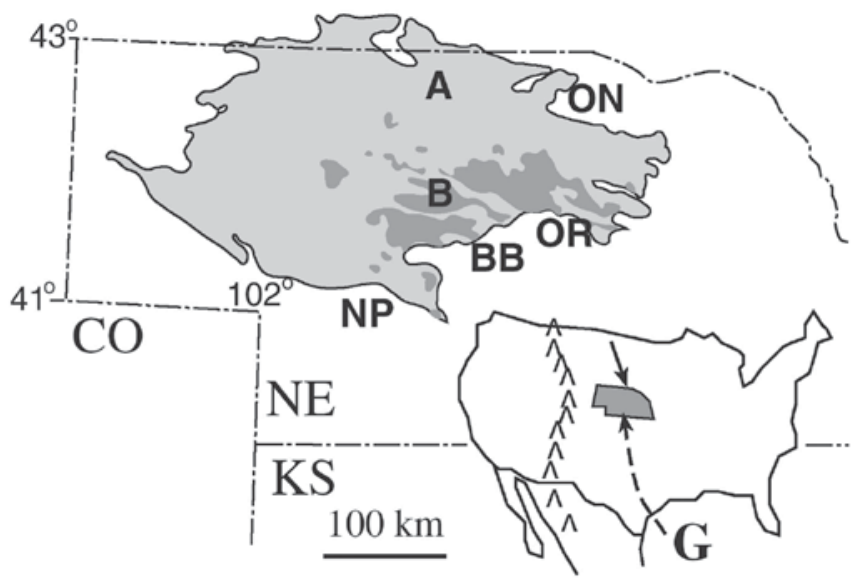

Ord, 1981-2005. The inset map shows Nebraska's position relative to the Rocky Mountains and Gulf of Mexico (G), modern winter winds (solid arrow), and modern spring-summer winds (dashed arrow).

Crests of Medieval dunes in the southeastern Sand Hills are oriented $\mathrm{N} 65^{\circ} \mathrm{W}$. These dunes are 12 to $15 \mathrm{~m}$ high and several km long, with $0.2-\mathrm{km}$ spacing (Figure S3). Cross-strata have bimodal dip directions (both NE and SW; Figure 2 and Figure S4), which is the key characteristic of longitudinal dunes (22). These structures indicate that the wind regime that shaped the dunes was not only bidirectional, but also that the two wind vectors were of nearly equal magnitude (Figure 2). Elongate dunes commonly join to form "y junctions" that are trustworthy indicators of resultant sand-drift direction (23). Because y junctions in the southeastern Sand Hills open toward the WNW (Figure S3), the resultant sand-drift direction for the Medieval dunes was ESE (Figure 2).

Hypothetical dunes that formed under the modern wind regime would thus be morpho-dynamically and structurally distinct from the ancient dunes, and the two would have crestal trends that diverge by $45^{\circ}$ to $60^{\circ}$. These differences show that wind directions and relative strengths have changed markedly since the 800-year-old dunes were active. The northerly vector lay between $340^{\circ}$ and $17.5^{\circ}$, and the southwesterly vector lay between $212.5^{\circ}$ and $250^{\circ}$ (Figure 2). If the dominant fall-winter-early spring (September to April) portion of the modern wind re- gime is retained as the northerly vector $\left(\sim 345^{\circ}\right)$, a relative strengthening (to become equal to the northerly vector) and a $70^{\circ}$ westward shift of the modern spring-summer winds would produce a dune trend, resultant vector, and internal structure that fit those of the Medieval dunes. A greater westward shift of the warm-season flow (regardless of wind strength) would reduce the divergence angle so that only transverse dunes form; a lesser shift would produce longitudinal dunes, but they would not produce NW-SE trends or y junctions opening to the WNW (Figure 2). Analysis of the dunes shows only that the sandtransporting northerly and southwesterly winds were similar in sand-transporting potential during the MWP drought. Assuming little significant change in the September-to-April wind regime at that time, southwesterlies would have been considerably stronger than the present southerlies and southeasterlies. Such a westward shift would also greatly reduce the flow of moist air into the central Great Plains, thereby generating severe drought.

Southwesterly flow of dry air across Nebraska is common in spring and summer in the modern regime but at the 850-millibar level ( $1200 \mathrm{~m}$ aloft) instead of at the surface (24). In spring and summer, strong heating of the land surface in the deserts of Mexico generates a deep, well-mixed layer of hot,
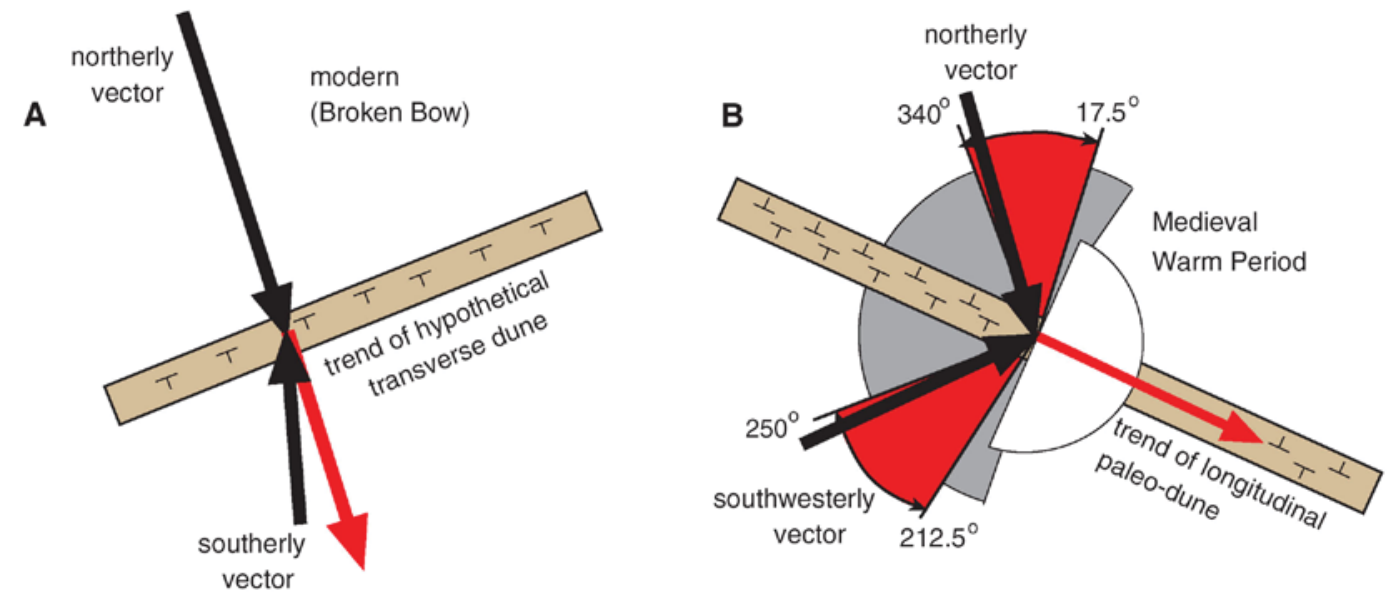

Figure 2. Modern and Medieval sand-drift vectors (directions of sand movement caused by main sand-transporting winds; bold black arrows), resultants (directions of sand movement resulting from net effects of all winds; red arrows), and trends of dune crests. Dip symbols ("Ts") show slope direction for sand layers (cross-strata) inside dunes and on downwind flanks. (A) Sand-drift vectors and resultant based on modern wind data from Broken Bow, Nebraska (simplified from Figure S2) and calculated trend of hypothetical dunes (19) (if sand were free to move). Migration of such dunes would generate sand cross-strata that would slope downward toward the SE. (B) Interpreted sand-drift vectors that generated NW-SE trend and bidirectional crossstrata (22) of Medieval longitudinal dunes.Y junctions (23) (Figure S2) indicate that the resultant is to ESE (not WNW), thereby excluding easterly vectors $\left(180^{\circ}\right.$ white sector).Vectors diverging less than $90^{\circ}$ and more than $165^{\circ}$ (gray sectors) would have generated transverse (not longitudinal) dunes ( 19,20$)$ (Figure SIC), thereby constraining the drift vectors to two $37.5^{\circ}$ sectors (red). The trend of longitudinal dunes bisects two subequal sand-drift vectors $(19,22)$. If, for example, the modern northerly (September through April) wind vector $\left(\sim 345^{\circ}\right)$ is retained from $(A)$, the southerly (May to August) vector must be rotated $\sim 70^{\circ}$ westward and strengthened to generate both the orientation and internal structure of the ancient dunes. 
dry air that moves to the northeast and eventually becomes elevated under the influence of the subtropical jet. Cooler, moister air from the Gulf of Mexico moves under the hot, dry air. The surface boundary between the moist air and the hot, dry air - the "dry line" reaches as far north and east as the Sand Hills several times each year at present, and it helps trigger outbursts of strong storms when it does so. Although it is ill-defined in a climatological sense, the mean position of the dry line at present is probably in eastern Wyoming or western Nebraska, well west of the Sand Hills. Our work suggests that during the MWP, the mean position of the dry line moved much farther east, such that the Sand Hills were most often in the dry, hot air with greatly reduced precipitation.

Under present conditions, dunes on the Plains-including those in eastern Colorado, central Kansas, and western Nebraska-are very near their threshold for mobilization $(6,25-28)$. The dunes discussed here, however, lie within the easternmost (wettest) portion of the Nebraska Sand Hills, which is an area that would presumably be among the last to activate if only slight alterations of the modern hydrological conditions and wind regime were necessary for dune mobility. Previous studies of Great Plains drought, including the Dust Bowl of the 1930s, have emphasized the importance of synoptic feedbacks associated with depleted soil moisture (23-25, 29-31). We interpret the southwesterly flow recorded by the longitudinal dunes of the eastern Sand Hills to be one of those feedbacks. When soil moisture is low, diurnal surface heating is very strong, and the momentum from winds aloft can be transferred to the land surface. Dry, southwesterly surface winds across the eastern Sand Hills were greatly enhanced after wetlands were desiccated (5), grass cover was breached, and sandy soils were exposed to direct solar radiation.

We used National Centers for Environmental Prediction/National Center for Atmospheric Research (NCEP/ NCAR) reanalysis data from 1949 to 2005 to determine if years of low precipitation corresponded with years when spring-summer surface flow was more westerly. Circulation composites for wet, dry, and normal years were constructed for May, June, and July. Although the Plains suffered severe droughts in the 1950s and 1970s, and experienced numerous dry (individual) years, the reanalyses do not show a westward wind shift. The NCEP/ NCAR reanalysis is model-dependent and has coarse resolution, therefore surface winds can be suspect. Further, by considering only monthly means, strong winds capable of sand transport may not be well-represented. Therefore, daily and monthly wind data for individual stations in central and western Nebraska were also examined. Again, no consistent westward shift was found, indicating that modern droughts and the Medieval drought cannot be explained by the same mechanism. Droughts of the last 57 years were relatively short and due more to diminished moisture convergence than to diminished moisture transport. The dunes record a historically unprecedented large-scale shift of circulation that removed the source of moisture from the region during the growing season. Eastward or southward migration of the North Atlantic subtropical ridge of high pressure (the "Bermuda High") likely initiated the Medieval drought (32), allowing midlevel southwesterly flow to descend. The drought may then have been enhanced and prolonged by reduced soil moisture and related surface-heating effects.

The MWP was a time of warmth and aridity throughout much of the western United States $(7,8,16)$; this suggests that the circulation change indicated by dune morphology is part of a larger climate anomaly (33). A switch in Pacific sea-surface temperature (SST) to a quasi-perennial "La Niña" state may be an important factor (33), because such an SST regime has been associated with drought throughout much of the western half of the United States (8). This concept may also help explain more pronounced episodes of aridity during the mid-Holocene, and it has seen recent support from climate modeling studies (34).

Acknowledgments - We thank D. Wedin, A. Houston, and K. Hubbard for helpful discussions and R. Goble and the Department of Geosciences for support of OSL dating. Our work is part of the Sand Hills Biocomplexity Project and was funded by NSF (grant nos. DEB 0322067 and BCS 0352683).

\section{References and Notes}

I. D. A. Wilhite, K. G. Hubbard, in An Atlas of the Sand Hills, A. Bleed, C. Flowerday, Eds. (Univ. of Nebraska Conservation and Survey Division Resource Atlas, Lincoln, NE, vol. 5a, 1990), p. 17.

2. D. B. Loope, J. B. Swinehart, J. P. Mason, Bull. Geol. Soc. Am. 107, 396 (1995)

3. D. B. Loope, J. B. Swinehart, Great Plains Res. I0, 5 (2000).

4. R. J. Goble, J.A. Mason, D. B. Loope, J. B. Swinehart, Quat. Sci. Rev. 23, II 73 (2004).

5. J. A. Mason, R. J. Goble, J. B. Swinehart, D. B. Loope, Holocene 14, 209 (2004).

6. D. R. Muhs, V. T. Holliday, Quat. Res. 43, 198 (I995).

7. C. A. Woodhouse, J.T. Overpeck, Bull. Am. Meteorol. Soc. 79, 2693 (1998).

8. E. R. Cook, C. A. Woodhouse, C. M. Eakin, D. M. Meko, D. W. Stahle, Science 306, 1015 (2004).

9. S. H. Millspaugh, C. Whitlock, P. J. Bartlein, Geology 28, 2 II (2000).

I0. J. A. Mohr, C. Whitlock, C. N. Skinner, Holocene I0, 587 (2000).

II.T.W. Swetnam, Science 262, 885 (1993).

I2. S. Stine, Nature 369, 546 (1994).

13. K. R. Laird, S. C. Fritz, K. A. Maasch, B. F. Cumming, Nature 384, 552 (1996).

14. J. M. Daniels, J. C. Knox, Holocene 15, 736 (2005).

15. K. J. Brown et al., Proc. Natl. Acad. Sci. U.S.A. 102, 8865 (2005).

16. T. J. Osburn, K. R. Briffa, Science 3II, 84I (2006).

17. N. Lancaster, Sedimentology 39,63I (1992).

18. N. Lancaster et al., Geology 30, 991 (2002).

19. D. M. Rubin, H. Ikeda, Sedimentology 37, 673 (1990).

20. G. Kocurek, in Sedimentary Environments: Processes, Facies and Stratigraphy, H. G. Reading, Ed. (Blackwell, Oxford, ed. 3, I 996), pp. I25153.

2I. S. G. Fryberger, in A Study of Global Sand Seas, E. D. McKee, Ed. (U.S. Geological Survey Professional Paper, vol. I052 1979), p. 137.

22. D. M. Rubin, R. E. Hunter, Sedimentology 32 , I 47 (1985).

23. D. S. G. Thomas, Z. Geomorph. 30, 23I (1986).

24. T. N. Carlson, Mid-latitude Weather Systems (HarperCollins, London, 199I), pp. 448481.

25. R. F. Madole, Quat. Sci. Rev. I4, 155 (1995).

26. A. F.Arbogast, J. Arid Environ. 34, 403 (1996).

27. R. F. Madole, Geology 22, 483 (1994).

28. D. R. Muhs, P. B. Maat, J. Arid Environ. 25, 35 I (1993).

29. S. D. Schubert, M. J. Suarez, P. J. Pegion, R. D. Koster, J. T. Bacmeister, Science 303, 1855 (2004).

30. R. D. Koster, M. J. Suarez, M. Heiser, J. Hydrometeorology I, 26 (2000).

3I. S. D. Schubert, M. J. Suarez, P. J. Pegion, R. D. Koster, J. T. Bacmeister, J. Clim. I 7, 485 (2004).

32. S. L. Forman, R. Oglesby, R. S. Webb, Global Planet. Change 29, I (200I).

33. R. S. Bradley, M. K. Hughes, H. F. Diaz, Science 302, 404 (2003).

34. S. Shin, P. D. Sardeshmukh, R. S. Webb, R. J. Oglesby, J. J. Barsugli, J. Clim. 19, 280 I (2006). 


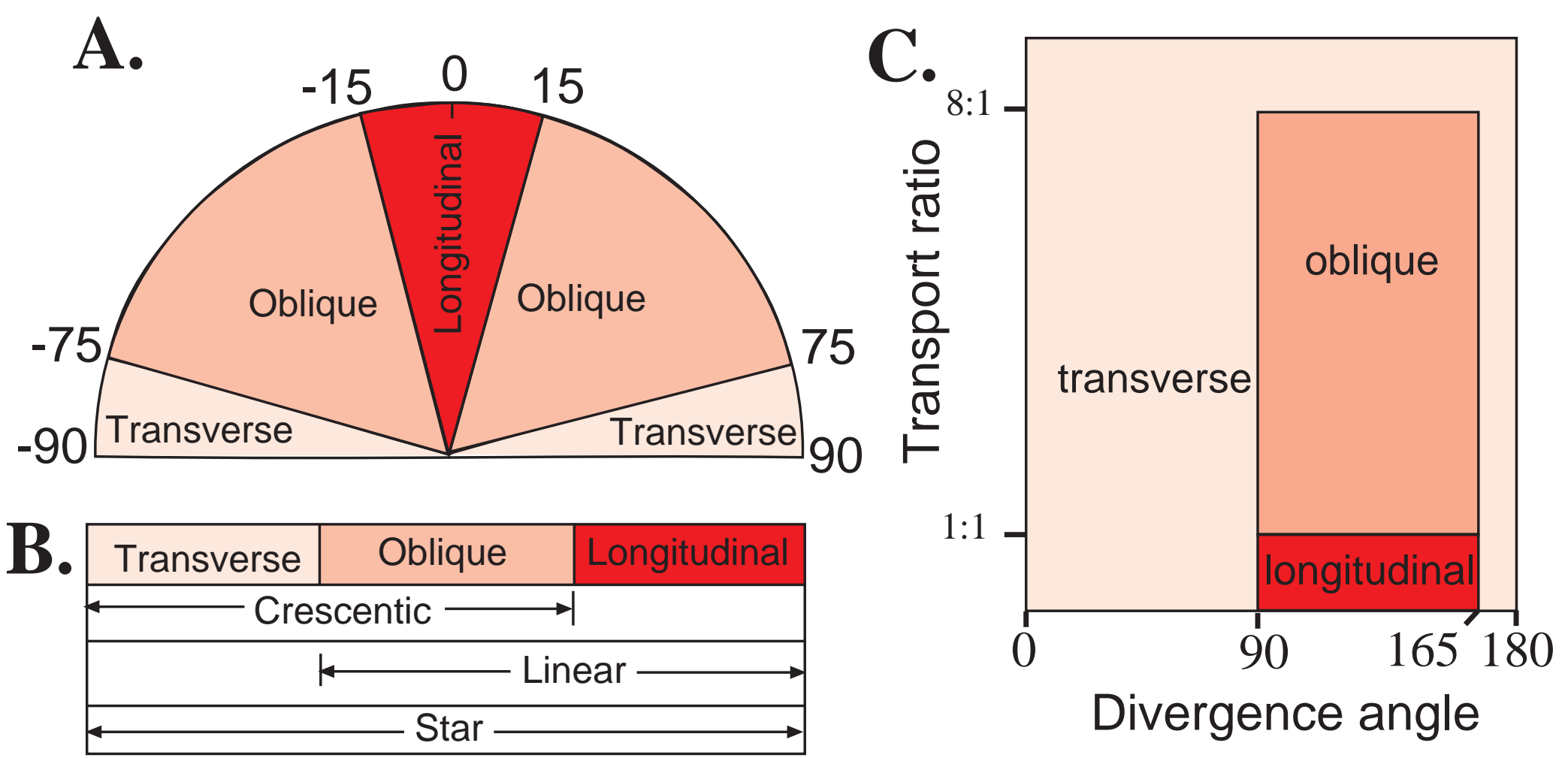

Fig S1. Dune types and wind regimes. A. Morphodynamic dune types based on angular relationship between dune trend and resultant transport vector. B. Range of morphological and morphodynamic dune types. C. Occurrence of morphodynamic dune types as a function of divergence angle of bidirectional flows and the proportions of sand transported in the two directions (transport ratio). ( $S 1$, S2) 


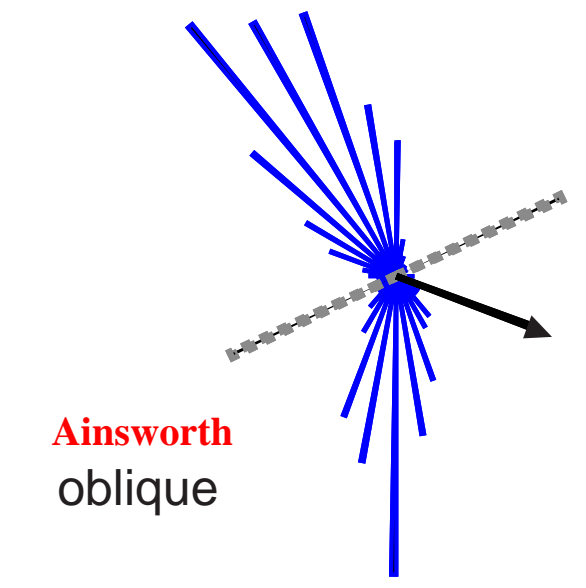

North Platte transverse

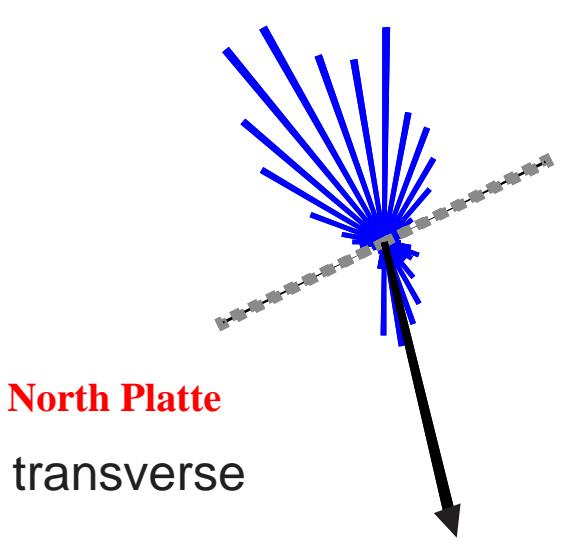

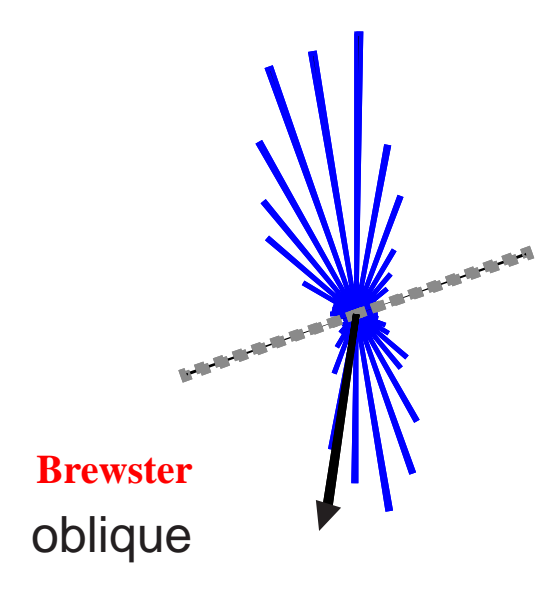

Broken Bow transverse

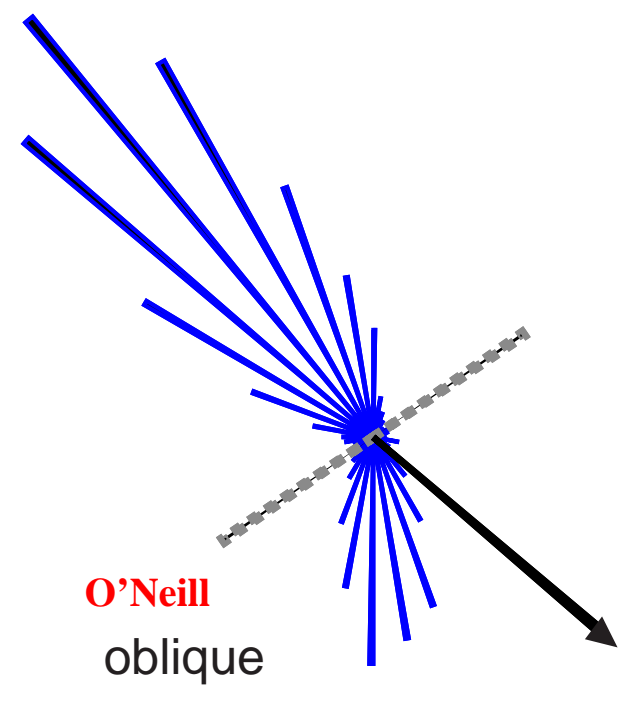

Ord

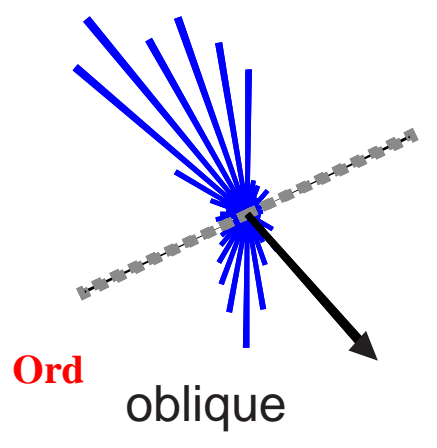

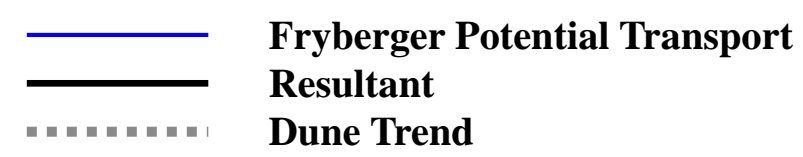

Fig. S2. Sand-drift roses for the 6 weather stations shown in Fig. 1. Roses show sand drift potential compiled with Fryberger method (S3) using wind data from National Climate Data Center. This method assumes the average diameter of erodible sand is $0.3 \mathrm{~mm}$, and the threshold velocity for sand movement is $5.9 \mathrm{~m} / \mathrm{sec}$. Blue lines point in the direction of sand-moving winds (above $5.9 \mathrm{~m} / \mathrm{sec}$ ); their lengths are proportional to the rate of potential sand movement (S4). Dashed grey lines show hypothetical dune trends (if sand were free to move under the modern wind regime) calculated using computer program Trend (S5). Black arrows show sand-drift resultant vectors. Dune type at each site is based on orientation of dune trend relative to resultant transport direction (S5). 


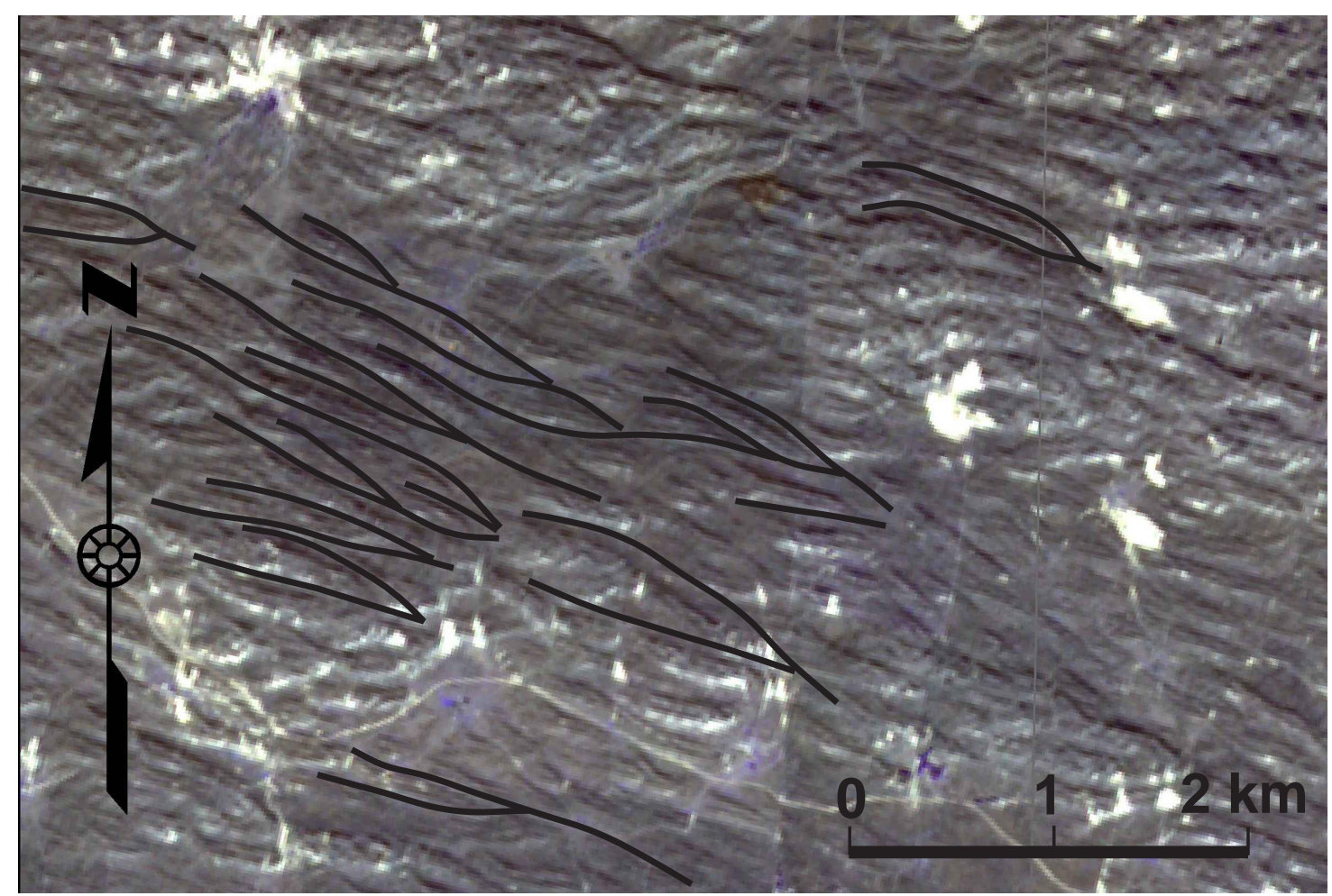

Fig. S3. ASTER image of longitudinal dunes, Nebraska Sand Hills. Lines mark dune crests and delineate y-junctions (S6) opening to the WNW; Thomas County, south of Dismal River.

Fig. S4a. Sedimentary structures and OSL ages from longitudinal dune; Cherry County, highway 97 , milepost 81
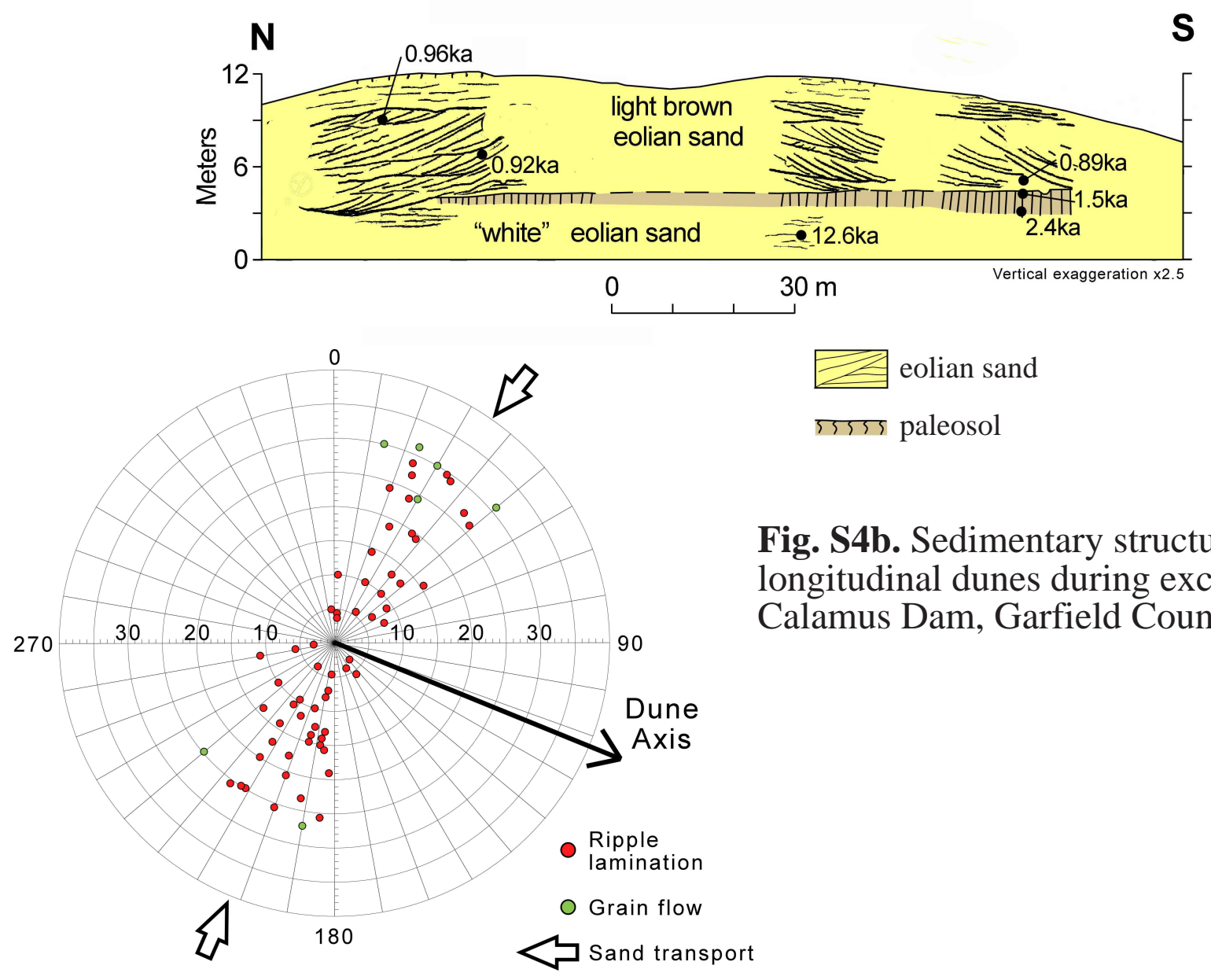

Fig. S4b. Sedimentary structures exposed in longitudinal dunes during excavation for Calamus Dam, Garfield County 


\section{Supplementary References}

S1. G. Kocurek, in Sedimentary Environments: Processes, Facies and Stratigraphy, $3^{\text {rd }}$

Ed, H.G. Reading, ed., Blackwell: 125-153 (1996).

S2. R.E. Hunter, B.M. Richmond, T.R. Alpha, Bull. Geol. Soc. Am. 94, 1450 (1983).

S3. S.G. Fryberger, in A Study of Global Sand Seas, E.D McKee, ed.: U.S. Geol. Surv. Prof. Paper 1052, 137 (1979).

S4. J.E. Bullard, Jour. Sed. Research 67, 499 (1997).

S5. D.M. Rubin, H. Ikeda, Sedimentology 37, 673 (1990).

S6. D.S.G. Thomas, Z. Geomorph. N.F. 30, 231 (1986). 